REVIEW ARTICLE

Goran Bašić

Ivana Stjelja**

\title{
DISCRIMINATION AND ROMA IDENTITY IN SERBIA
}

\begin{abstract}
The paper was based on contemporary legal, sociological and anthropological literature concerning the issues of discrimination and integration of Roma, as well as on the data obtained in two research projects realised in 2020: "Research on Social Relations among Ethnic Communities in Serbia" (Institute of Social Sciences) and "Roma Equality through Increased Legal Access" (Minority Rights Group). Results of the former project were based on data collected by quantitative methods (national internet sample and field research), while those of the latter were gathered by means of qualitative methods, i.e. interviews with 42 female and 17 male respondents realised in eight focus groups. Crossing the empirical data pertaining to discrimination of the Roma citizens living in Serbia, with the legislative system which should supress and gradually eliminate all forms of discrimination, indicates the depth of the social dimension of this problem, but also the vagueness and deficiencies of the very system.
\end{abstract}

Key words: Roma, discrimination, antigypsyism, social inclusion.

\section{INTRODUCTION}

In the contemporary literature dedicated to the position of Roma, a conclusion is reiterated that discrimination is the key obstacle to social inclusion and realisation of the social and legal equality for the members of the Roma nation. In spite of the fact that, in Europe, anti-discriminatory policies are developed and national programmes of Roma integration and inclusion are stimulated, the efforts are inefficient and thus require review and reconceptualization based on valid data.

* Principal Research Fellow, Director, Institute of Social Science, Belgrade;

e-mail: basicgoran11@gmail.com

** Associate, Institute of Social Sciences, Belgrade, Doctoral Candidate, Union University Law School Belgrade, Belgrade; e-mail: ivana.stjelja@gmail.com 
In this paper, based on the empirical data from current research on discrimination ${ }^{1}$ and social distance towards Roma ${ }^{2}$ in Serbia crossed with other facts and European anti-discriminatory policies, we strive to identify contemporary causes for the phenomenon of Roma discrimination. The analyses of the social position and legal aspects of discrimination in this paper are based on updated and valid quantitative and qualitative data. The research on social distance was realised in 2020, using a combined survey method: a representative internet sample of Serbian citizens and field research, while the research on discrimination was implemented as interviews at nine focus group discussions with different target groups (Roma living in substandard settlements, youth, Roma women, civil society organisations, lawyers representing Roma in discrimination cases, public administration representatives, etc.).

The main intention of this paper is to stimulate reflection within the scientific and professional community about the necessity of integrated national policies of the social inclusion of Roma, with a holistic focus on solving the problems of poverty, prejudices and stereotypes, both among Roma and members of other ethnic groups. The empirical data which indicate the existence of a pronounced social distance towards Roma, but also vice versa, as well as absence of efficient anti-discriminatory measures in the public policies of education and culture, confirm justification of the initial approach to the problem of discrimination.

The legal concepts of anti-discriminatory policy, such as free legal aid, or the proceedings led before courts, even those initiated by the Ombudsperson for the Protection of Equality, are not central to this paper. Judicial and other legal mechanisms for the protection of citizens' rights are certainly important tools in the process of eliminating discrimination and they deserve to be comprehensively researched and analysed. However, we currently lack the data on the effects of few strategic civil litigations concerning discrimination, while the data on operation of courts and other public authorities before which Roma should realise their right to protection of equality are even sparser. Due to the lack of data essential to any scientific and professional analysis, in this paper, apart from describing them, we did not engage in any comprehensive analysis of legal anti-discriminatory mechanisms.

1 Bašić, G., 2021, Roma in the Republic of Serbia: The Challenges of Discrimination, Minority Rights Group, London, pp. 1-28.

2 Bašić, G. et al., 2020, Istraživanje socijalnih odnosa izmedu etničkih zajednica u Srbiji, Beograd, Centar za istraživanje etniciteta, Institut društvenih nauka, (http://idn.org. rs/sr_lat/wp-content/uploads/2020/09/SOCIJALNA-DISTANCA-ETNICKIH-ZAJEDNICA-IZVESTAJ.pdf, 15. 3. 2021). 


\section{Roma in Contemporary Society}

Majority of the contemporary scientific, professional and popular literature dedicated to the position and living of Roma indicates that discrimination represents a major obstacle to their social integration. ${ }^{3}$ It is a widespread opinion that the roots of the discrimination lie in the prejudices against Roma, transferred transgenerationally among members of other ethnic communities. The discrimination is most frequently rooted in the stereotype that Roma are less inclined to hard work and not capable of engaging with contemporary social tendencies due to their specific lifestyle. ${ }^{4}$ The consequences of discrimination against and aversion to Roma in Serbia were the most striking during World War II, ${ }^{5}$ yet even today, Roma face social and spatial segregation, as well as limited access to justice and rights.

Trying to eliminate discrimination against Roma in the European Union and the states gravitating towards joining this political and social space, European Commission, Council of Europe and other international organisations have developed anti-discriminatory policies and established corresponding mechanisms and instruments. ${ }^{6}$ Furthermore, in recent years, a lively discussion have been going on when it comes to combating antigypsyism in Europe. ${ }^{7}$ European Court of Human Rights increasingly deliberates on the petitions concerning violations of the right to equality

3 Ignãțoiu-Sora, E., 2011, The Discriminations Discourse in Relation to the Roma: Its Limist and Benefits, Ethnic and Racial Studies, Vol. 34, Issue 10, pp. 1697-1714; Ram, M., 2007, Anti-discrimination Policy and the Roma Assessing the Impact of EU Enlargement, Croatian Yearbook of European Law \& Policy, No. 3, pp. 491-513.

4 Bašić, G., 2021, p. 6.

5 When it comes to the tribulations of Roma in WWII see: Pisari, M., 2014, Stradanje Roma u Srbiji za vreme Holokausta, Belgrade, Forum za primenjenu istoriju, pp. $1-153$.

6 See: ECRI General Policy Recommendation No. 13 revised on combating antigypsyism and discrimination against Roma - adopted on 24 June 2011 and amended on 1 December 2020; EU Council Directive 2000/43/EC of 29 June 2000 implementing the principle of equal treatment between persons irrespective of racial or ethnic origin (OJL 180, 19. 7. 2000, pp. 22-26); EU Council Directive 2000/78/EC of 27 November 2000 establishing a general framework for equal treatment in employment and occupation (OJL 303, 2. 12. 2000, pp. 16-22), etc.

7 Hancock, I., 1995, Posledice anti-romskog rasizma u Evropi, Pravo i rat, Beogradski krug, str. 221-227; Fejzula, S., 2019, The Anti-Roma Europe: Modern ways of disciplining the Roma body in urban spaces, Revista Diretio e Praxis, Vol. 10, No. 3, Rio de Janeiro July/Sept., pp. 2097-2116; Nicolae, V., Towards a Definition of Anti-Gypsyism, in: Nicolae, V., Slavic, H., (eds.), 2007, Roma Diplomacy, International Debate Education Association, New York, DiploFoundation, pp. 19-28. 
of Roma nationals. ${ }^{8}$ Finally, in the European context and national policies, significant attention is dedicated to the policies and programmes of longterm Roma integration, which should serve to achieving elimination of the discrimination of Roma and their social inclusion. ${ }^{9}$

However, despite ever developing anti-discriminatory policy, reports on realisation and protection of the human rights of Roma still evidence discrimination and social distancing when it comes to Roma, ${ }^{10}$ which has become particularly evident during the Covid-19 pandemic. According to the research realised in 2020 by the Open Society Foundation in six states of the EU, it is established that their authorities "have not responded with proportionate attention to the much higher risk of death from COVID-19 in Roma communities". ${ }^{11}$ In their Bulletin published in September 2020, Agency for Fundamental Rights of the EU warned that hate speech and discrimination against Roma have been on the rise during the pandemic, since many citizens believed that Roma are to be blamed for the spreading of the virus. ${ }^{12}$

A long lasting exposure to discrimination and insufficiently efficient anti-discriminatory public policies still discourage many members of the Romany community, and they often tend to conceal their ethnic origin by adopting the identity of the ethnic groups living in their vicinity. However, in today's Europe, social and political ties between Roma groups are being strengthened, favouring the strengthening of national awareness and revitalisation of the movement which in the second half of the $20^{\text {th }}$ century put on the political agenda questions vital for the preservation of the identity and realisation of the rights of Roma. ${ }^{13}$

It needs to be mentioned that for a long time, the aforementioned EU directives and the ECRI Recommendation No. 13 on Combating Antigypsyism and Discrimination against Roma used to be the only instruments

8 See: Factsheets - Roma and Travellers, (https://www.echr.coe.int/documents/fs_ roma_eng.pdf, 2. 3. 2021).

9 See: COM/2018/785: Communication From the Commission to the European Parliament and the Council, Report on the evaluation of the EU Framework for National Roma Integration Strategies up to 2020.

10 Chopin, I., Germaine, C., Tanczos, J., 2017, Roma and the Enforcement of Anti-Discrimination Law, European Commission, Directorate - General for Justice and Consumers, pp. 1-32.

11 Korunkovska, N., Jovanović, Ž., 2020, Roma in the COVID-19 Crisis - An Early Warning from Six EU Member States, Open Society Foundation, pp. 1-14.

12 Coronavirus pandemic in the EU - impact on Roma and Travellers - Bulletin 5, 2020, EU Agency for Fundamental Rights, (https://fra.europa.eu/en/publication/2020/covid19-rights-impact-september-1, 27. 3. 2021).

13 Bašić, G., 2010, Politička akcija - romski pokret i promene, Beograd, Čigoja, p. 19. 
in combating and alleviating the consequences of discrimination, which members of the Roma community have continuously faced since their settlement in Europe in the $14^{\text {th }}$ century. ${ }^{14}$ However, since 2010, in the EU, a programme has been developed, which implies the improvement of the social and economic position of Roma and realisation of their social integration. The basis for the policy of social integration of Roma was established on 7 April 2010, with the adoption of document COM/2010/0133 "Communication from the Commission to the Council, the European Parliament, the European Economic and Social Committee and the Committee of the Regions - The Social and Economic Integration of the Roma in Europe". The aim of this programme was to eliminate the practice of social and spatial segregation of the Roma in Europe and to tackle the challenge of integration in a systemic way, through corresponding European and national policies. The discrimination of Roma was not highlighted in that document as to the main obstacle in realisation of the integration process. The policy of stimulating the social integration of Roma was confirmed in the Recommendation of the Council of the European Union on effective Roma integration measures in the Member States through employment, social policy, healthcare and consumer affairs. In this document, the Member States were recommended to create and implement both fundamental measures that promote equality and improve social and economic position of Roma, and horizontal measures directly aimed at combating discrimination and antigypsyism. ${ }^{15}$

Evaluation of this programme has not been performed in an appropriate way, primarily due to the lack of valid data. Yet, that the combating efforts to tackle the discrimination of Roma have been facing serious challenges is also indicated by the aforementioned analysis by the European Commission ${ }^{16}$ which shows that between 2011 and 2015, the results achieved in combating discrimination were not encouraging; what is more, the situation deteriorated in five out of twenty seven Member States. It has been established that the unfavourable social and economic position of Roma is the main cause for such situation, since it directly impacts abilities of the members of this ethnic group to realise their recognised rights. However, Member States also fail to allocate sufficient funds in their budgets for integration programmes, which also prevent Roma people from achieving

14 Soulis, G. C., 1961, The Gypsies in the Byzantine Empire and the Balkans in the Late Middle Ages, Dumbarton Oaks Paper, Vol. 15, Harvard University, pp. 141-165.

15 Council recommendation on effective Roma integration measures in the Member States - employment, social policy, health and consumer affairs, Council meeting, Brussels, December 9-10, 2013, (https://www.consilium.europa.eu/uedocs/cms_ data/docs/pressdata/en/lsa/139979.pdf, 15. 4. 2021).

16 Chopin, I., Germaine, C., Tanczos, J., 2017, pp. 1-32. 
equality. Similar observations are also present in the Report on the evaluation of the EU Framework for National Roma Integration Strategies up to 2020, which, in addition to emphasising the importance of the overall Roma policy in the European Union and the progress made in education, indicates that the segregation has remained an unsolved challenge, that the progress in healthcare is limited and that there are no improvements when it comes to access to employment and housing, while antigypsyism and hate crimes against Roma are still causing concern. ${ }^{17}$

The condition and perspectives of the "Roma question" in today's Europe have been summarised in a couple of sentences by Roma activist Željko Jovanović:

We have learned, hopefully, three major lessons. First, the interest of the state for the accession to the EU is not sufficient in itself. Without wider national political consensus and will, no system can be changed and therefore no major improvement for our community can be achieved. Second, prejudices against Roma are no longer within the domain of the personal thinking, but they instead are a political weapon, since politician did learn that they could use them to manipulate public opinion and thus get cheap votes, which has a direct negative effect on the Roma situation. Such politicians realised that it is cheaper to have a policy against Roma, than policies that would create employment opportunities, improve healthcare services, decrease corruption and improve education. Third, we Roma must rely on ourselves and work with those who are our friends. We can no longer wait for the EU, international organisations and donors to implement our policies and protect our interests more than we do that ourselves. They can only help, but we must lead the way forward. ${ }^{18}$

\section{Social and Political Aspects of the Discrimination Against Roma in Serbia}

\subsection{HISTORICAL PERSPECTIVE}

It is often pointed out that the Roma in Serbia shared the destiny of the majority population, especially throughout world wars and frequent regional conflicts. The oeuvre of historian Milovan Pisari ${ }^{19}$ and

17 COM/2018/785: Communication From the Commission to the European Parliament and the Council, Report on the evaluation of the EU Framework for National Roma Integration Strategies up to 2020.

18 Interview: Željko Jovanović: Ne možemo više da čekamo da EU, međunarodne organizacije i donatori vode našu politiku, 2019, the Udar internet portal, (http://www. portal-udar.net/zeljko-jovanovic-ne-mozemo-vise-da-cekamo-da-eu-medunarodneorganizacije-donatori-vode-nasu-politiku/, 5. 4. 2021).

19 Pisari, M., 2014, p. 35. 
others ${ }^{20}$ emphasise huge human losses of the Roma people in Serbia during the world wars, yet it is less known that Roma did actively participate in the national liberation movements in Serbia, during the uprisings between 1804 and $1818,{ }^{21}$ or that all the way to WWII, in spite of the poverty and marginalisation of the group, there was an ever increasing number of Roma public figures, actors, tradesmen, craftsmen, lawyers, while Romany newspapers were printed and sport associations founded. ${ }^{22}$ The social atmosphere of the time was strikingly described in an article published in Politika daily on 18 August 1922:

\section{A Gipsy and a General}

One of our Gipsies playing nightly in Belgrade taverns, has erected recently a handsome home at Cubura, where the entire musician's family has comfortably settled. Even though furniture is ludicrously expensive nowadays, the Gipsy has upholstered all his rooms and bought himself even a piano. In order for his son to learn piano in addition to violin, so that he could subsequently perhaps become the leader of a band in some bar, the old Gipsy found a Russian General to be his son's piano teacher. This unfortunate brother of ours, to whom our state and society failed to provide some other kind of sustenance, thus frequents daily that Gipsy home and teaches piano to the Gipsy's son. The old Gipsy has become a wealthy boss. His orchestra earns up to 5000 dinars for single night. Once his orchestra would include a piano, and thus can play bars, the profit would increase. A Gipsy and a General. Oh, how the times change!

In the decades preceding WWII, Belgrade was acquiring semblance of a European capital, through urban planning efforts, where the urban plans paid meticulous attention to resettlement of poor citizens from their improvised homes. The majority of these were of Roma origin. ${ }^{23}$ In other words, in spite of all the difficulties and problems that Roma were faced with, the process of their integration in that time was spontaneous and it seems that it had results comparable to those of today's integration and inclusion plans. World War II annulled spiritual and

20 Trubeta, S., 2003, Gypsiness, Racial Discourse and Persecution: Balkan Roma during the Second World War, Nationalities Papers The Journal of Nationalism and Ethnicity, Vol. 31, pp. 391-411.

21 Stojančević, V., Politički i pravni položaj Cigana (Roma) u Srbiji Prvog i Drugog ustanka, in: Macura, M., (ed.), 1992, Razvitak Roma u Jugoslaviji, problemi i tendencije, Beograd, Srpska akademija nauka i umetnosti, p. 28.

22 See: Acković, D., 2009, Romi u Beogradu: istorija, kultura i tradicija Roma u Beogradu od naseljavanja do kraja XX veka, Beograd, Rominterpres.

23 Macura, Z., 2015, Život na ivici. Stanovanje beogradskih Roma, Beograd, Galerija SANU. 
humanist development of civilisation and revitalised tribalism and crimes which, after the collapse of fascist ideology, would periodically reoccur in different parts of the world. Jews and Roma were particularly exposed to persecution and racist bestiality, the consequences of which still have their impact on the lives of modern generations. From fifth to ninth decade of the $20^{\text {th }}$ century, the Roma in Serbia experienced a stimulating period of emancipation, ${ }^{24}$ when they finally accepted sedentary lifestyle, involved themselves in education and labour and, finally, created their strong intellectual elite. Roma from Serbia actively participated in the creation and development of the European Roma movement and political awakening of their compatriots. ${ }^{25}$ However, the dissolution of Yugoslavia and mass violations of human rights on its territory were detrimental for the positive effects of the process of integration of Roma in Serbia, as they rekindled hostility, prejudices and discrimination. ${ }^{26}$ The collapse of the political and economic system caused general impoverishment which was conducive to deterioration of the Roma integration programmes aimed at eradication of structural poverty and promotion of social inclusion of the group. At the turn of the $21^{\text {st }}$ century, Serbian Roma were once again faced with forced migrations, violence, social neglect, the process of combating poverty was discontinued, and in the conditions of ethnocentrism and ethnification of the society, the social climate in which discrimination is a part of the natural habitus was shortly renewed.

\subsection{CONTEMPORARY CONTEXT}

When it comes to policies, in the contemporary context, the Republic of Serbia initiated activities the purpose of which was an improvement of the social and economic conditions and combating discrimination. The involvement in the multinational initiative "Decade of Roma Inclusion", implemented in Southeast Europe from 2005 to 2015, and adoption of the national strategies in 2010 and $2016,{ }^{27}$ that of integration and social inclusion of Roma, as well as the Strategy for the Prevention of and

24 Institucionalizacija i emancipacija, 2010, Romi i istorija, No. 6.2, Savet Evrope, (https://rm.coe.int/institucionalizacija-i-emancipacija-informativna-brosura-o-istoriji-ro/16808b1c67, 31. 3. 2021).

25 Bašić, G., 2010, p. 37.

26 Jakšić, B., 2015, Romi u Srbiji između nakovnja siromaštva i čekića diskriminacije, Beograd, MostArt, p. 35.

27 Strategy for the Social Inclusion of Roma Men and Women in the Republic of Serbia for the period of 2016-2025, Official Gazette of RS, No. 26/16. 
Protection from Discrimination, ${ }^{28}$ as well as of the Law on Prohibition of Discrimination, resulted in the creation of a solid legal basis for institutional and social action against structural poverty and discrimination. However, after more than a decade of implementing these measures, it is often heard in public that "Anti-Gypsyism, cumulative discrimination, prejudices towards and wrong perceptions of Roma prevail in Serbia as in all other countries in Europe. Anti-Gypsyism and cumulative and systematic discrimination constitute the root-causes for their social exclusion, while high unemployment rates, low education enrolment and attainment rates and the deplorable living conditions of the majority are the symptoms of their situation." ${ }^{29}$ Commissioner for the Protection of Equality confirms these findings:

Results of the research on discrimination against Roma have confirmed that they are exposed to direct or indirect discrimination in all spheres of life. [...] when it comes to discrimination against Roma, prevalent are the stereotypes and prejudices. [...] Cultural and political patterns lying behind these cannot be changed by a single institution. What is necessary is the synergy of all governmental and non-governmental actors. ${ }^{30}$

Research on social relations between the ethnic communities in Serbia indicates that in Today's Serbia Roma men and women most frequently encounter discrimination in their everyday contacts with their neighbours, colleagues, or when they perform routine social actions. What is striking in the pattern of discrimination against Roma, is that they are exposed to it at an early age, in contacts with their peers, and that it is manifested during their schooling, employment, professional engagement and before institutions (Graph 1). ${ }^{31}$

28 Strategy for the Prevention of and Protection from Discrimination, Official Gazette of $R S$, No. $60 / 13$.

29 The Wall of Anti-Gypsyism - Roma in Serbia, 2018, Civil Rights Defenders, (https:// crd.org/wp-content/uploads/2018/03/The-Wall-of-Anti-Gypsyism-Roma-in-Serbia. pdf, 7. 4. 2021).

30 Interview, Poverenica: Romi su izloženi diskriminaciji u svim oblastima života, Beta, 2020, (https://rs.nlinfo.com/vesti/a683369-poverenica-romi-su-izlozeni-diskriminaciji-u-svim-oblastima-zivota/, 9. 4. 2021).

31 Bašić, G., 2021, p. 7. 


\section{Graph 1}

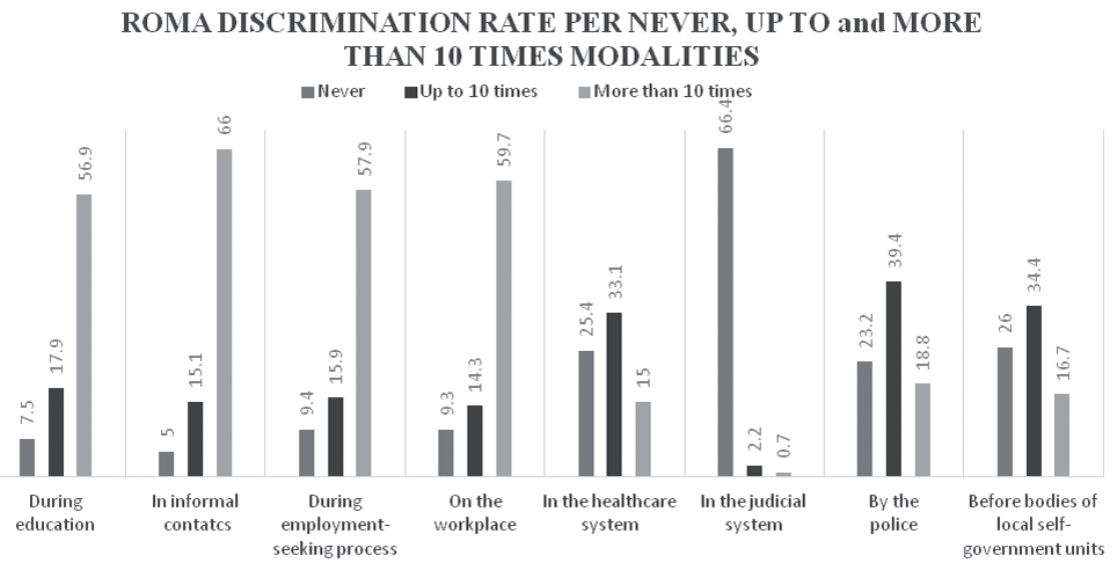

Source: Research of social relations between the ethnic communities in Serbia, Institute of Social Sciences, 2020

Discrimination against Roma is based on the prejudices and stereotypes of the majority population and the six ethnic groups included in the sample. One in two respondents on average would accept Roma as their neighbours, while one in five respondents would accept Roma as their spouse ${ }^{32}$ (Graph 2).

\section{Graph 2}

\section{SOCIAL DISTANCE TOWARDS ROMA IN SERBIA}

- Neighbourhood Marriage

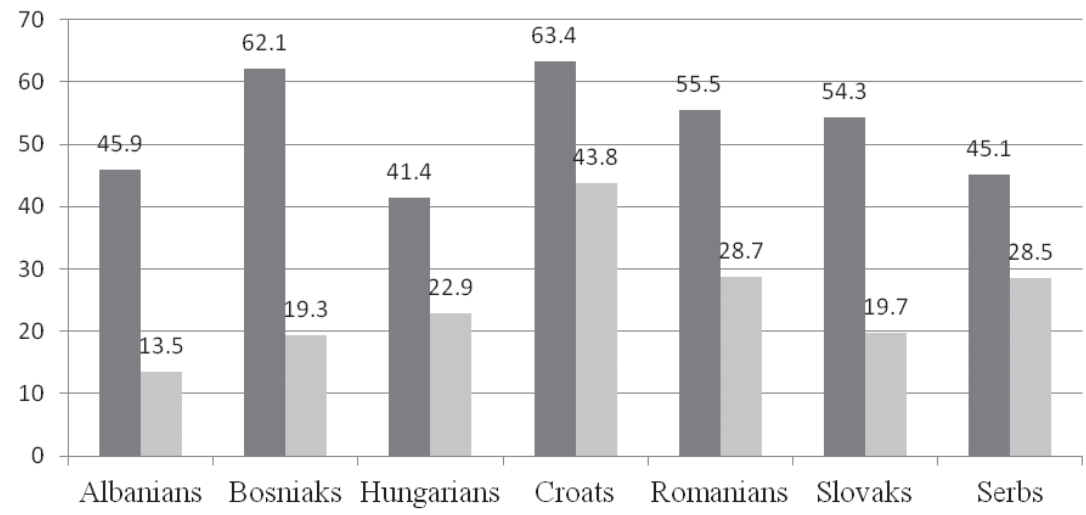

Source: Research of social relations between the ethnic communities in Serbia, Institute of Social Sciences, 2020

32 Bašić, G., 2021, p. 9. 
In the interviews conducted during the focus groups realised in the research project Roma Equality through Increased Legal Access, personal experiences were recounted, largely confirming this pattern. Truth be told, rare testimonies indicated that there were Roma nationals who had never experienced discrimination, yet these very same citizens had firm opinions about the consequences of discrimination and prejudices against Roma. There was a striking testimony of a university educated Roma woman who participated in the focus group, that she had never experienced direct discrimination, yet she felt that the prejudices against her ethnicity represented an obstacle in her achieving her full social and professional affirmation. During schooling and university studies, she said, she had needed to be two times more successful than her peers to achieve the same results. Even though she had applied numerous times for jobs in the public sector and private companies, she had never been offered a contract for more than a couple of months, while the privately owned business that she had, was burdened by prejudices that service beneficiaries had concerning her nationality. Finally, her children were facing the identical problems that she had faced - being ignored by other children, feeling ashamed when Roma were talked about with contempt and derision and experiencing diminished interest of the teachers for their school attainment. ${ }^{33}$

Finally, we also researched the consequences caused by the lasting discrimination, when it comes to the identity and social attitudes of Roma. The initial thesis was derived from Charles Taylor's theory that group identity is "partly shaped by recognition or its absence, often by the misrecognition of others, and so a person or group of people can suffer real damage, real distortion, if the people or society around them mirror back to them a confining or demeaning or contemptible picture of themselves. Nonrecognition or misrecognition can inflict harm, can be a form of oppression, imprisoning someone in a false, distorted, and reduced mode of being." ${ }^{34}$ This hypothesis, even though we generally deem it to be correct, has not been entirely proven, providing that in the 2020 Research by the Institute of Social Sciences, as much as $86.4 \%$ of Roma respondents demonstrated pronounced national pride, while $81.2 \%$ of them had deeply embedded awareness of the importance of national history. ${ }^{35}$

Additionally, the Research collected the data on personal and presumed (expected) opinions of close relatives and friends concerning Roma, from the members of seven ethnic groups in Serbia.

33 Bašić, G., 2021, p. 9.

34 Tejlor, Č., 2000, Politika priznanja, Habitus, No. 1, Novi Sad, p. 19.

35 Bašić, G. et al., 2020, p. 275. 
Graph 3.

ROMA: CLOSENESS TO OTHERS -

PERSONAL AND PERCEIVED OPINIONS

Modality: I fully agree

\begin{tabular}{|c|c|c|c|c|c|c|}
\hline & Cohabitation & Neighbourhood & Acquaintances & Colleagues & Friends & Marriage \\
\hline $\begin{array}{l}\text { "Albanians } \\
\text { personal" }\end{array}$ & 61.1 & 54.2 & 63.9 & 62.5 & 62.8 & 31.1 \\
\hline $\begin{array}{l}\text { "Albanians } \\
\text { perceived" }\end{array}$ & 38.9 & 25.3 & 39.8 & 40.5 & 31.9 & 15.3 \\
\hline $\begin{array}{l}\text { "Bosniaks } \\
\text { personal" }\end{array}$ & 77.4 & 69.7 & 74.4 & 76.3 & 73.8 & 41.6 \\
\hline $\begin{array}{l}\text { "Bosniaks } \\
\text { perceived" }\end{array}$ & 54.8 & 35.9 & 51.4 & 49.9 & 42.2 & 18.5 \\
\hline $\begin{array}{l}\text { "Hungarians } \\
\text { personal" }\end{array}$ & 72.4 & 64.1 & 73.2 & 72.7 & 73.2 & 36.4 \\
\hline $\begin{array}{l}\text { "Hungarians } \\
\text { perceived" }\end{array}$ & 57.1 & 46.1 & 55.5 & 55.8 & 49.8 & 23.7 \\
\hline $\begin{array}{l}\text { "Croats } \\
\text { personal" }\end{array}$ & 72.8 & 68.4 & 74.1 & 73.8 & 73 & 41.9 \\
\hline $\begin{array}{l}\text { "Croats } \\
\text { perceived" }\end{array}$ & 49.9 & 39.7 & 49.1 & 47.7 & 44.7 & 16.8 \\
\hline $\begin{array}{l}\text { "Romanians } \\
\text { personal" }\end{array}$ & 76.7 & 70.6 & 77.2 & 77.6 & 76.8 & 42.7 \\
\hline $\begin{array}{l}\text { "Romanians } \\
\text { perceived" }\end{array}$ & 63.2 & 55.3 & 62.1 & 61.7 & 58.1 & 34.1 \\
\hline $\begin{array}{l}\text { "Slovaks } \\
\text { personal" }\end{array}$ & 73.8 & 70.1 & 76.8 & 77.4 & 76.2 & 36.9 \\
\hline $\begin{array}{l}\text { "Slovaks } \\
\text { perceived" }\end{array}$ & 58.9 & 52.2 & 58.8 & 59.1 & 55.9 & 32.4 \\
\hline $\begin{array}{l}\text { "Serbs } \\
\text { personal" }\end{array}$ & & 86.8 & 92.4 & 91.4 & 87.8 & 64.4 \\
\hline $\begin{array}{l}\text { "Serbs } \\
\text { perceived" }\end{array}$ & & 81.4 & 84.5 & 81.2 & 80.7 & 61 \\
\hline
\end{tabular}

Source: Research of social relations between the ethnic communities in Serbia, Institute of Social Sciences, 2020

These data refute the thesis that Roma are more readily available for intercultural exchange than other ethnic groups, since Roma did not demonstrate the expected closeness with the participating groups of citizens. Graph 3 provides the data, and for the sake of illustration, we shall point to the fact that one in four Roma respondents would gladly accept Albanian 
neighbours, one in three would accept Bosniaks, every other would accept Croats or Hungarians. Marriage with an Albanian national is acceptable for $31.1 \%$ Roma respondents, while $36.4 \%$ would marry a Hungarian national. Serbs are the most acceptable as spouses for $64.4 \%$ of the Roma respondents. The trends identified in the research draw attention to the fact that Roma nationalism is rarely spoken of, though it is certainly possible. ${ }^{36}$

One should bear in mind that Roma integration or inclusion policies cause changes in the group identity. Literature ${ }^{37}$ quotes measures implemented in the past with the aim of improving the position of Roma, which had their impact on Roma tradition and language. Sedentary lifestyle, ethnic mimicry, the disappearance of the traditional national foundations, such as Roma court of justice (Rromani kris) ${ }^{38}$ or changes in the language (Rromani ćhib) ${ }^{39}$ also influenced lasting changes in the identity of Roma (Rromanipen). ${ }^{40}$ After these negative experiences of the past, present-day measures should not lead to unwilling changes in the group identity, with the consequences equal to those produced by discrimination. In other words, one should bear in mind that discrimination in itself results in the changes of Roma identity, yet combating against it with measures which are not thoroughly planned and are adopted without the agreement with and participation of Roma people, may also lead to negative consequences when it comes to the group's identity.

\section{Legal Aspects of the Prohibition of Discrimination Against Roma in Serbia}

\subsection{GENERAL OVERVIEW}

Constitution of the Republic of Serbia guarantees equality to all the citizens before the Constitution and the law, as well as the right to "equal legal protection, without discrimination". ${ }^{41}$ Both types of discrimination,

36 Bašić, G., 2021, p. 10.

37 Matasović, J., 1928, Cigani u doba terezijanstva i jozetinizme, Zagreb, Narodna starina.

38 Weyrauch, W., 2001, Gypsy Law Romani Legal Traditions and Culture, University of California Press.

39 Courthiade, M., 2018, Consolidating the Standardization of the Romani Language - Past, Present, Future, in Respect of Dialectal Diversity while Granting Easy Worldwide Communication in Mother Tongue, in: Sikimić, B., Varady, T., Očuvanje, zaštita i perspektive romskog jezika u Srbiji, SASA, Beograd.

40 Mirga, A., 1987, The Category of "Romanipen" and the Ethnic Boundaries of Gypsies, Ethnologia Polona, Vol. 13, pp. 243-255.

41 Art. 21, Para 1 \& 2, Constitution of the Republic of Serbia, Official Gazette of RS, No. 98/06. 
i.e. direct and indirect, are explicitly prohibited by the Constitution. The most frequent grounds for discrimination are also explicitly mentioned: "Race, sex nationality, social background, birth, confession, political or other belief, material status, culture, language, age and mental or physical disability", and that discrimination is also prohibited on any other ground, in addition to these. ${ }^{42}$ In other words, this is an open clause of grounds of discrimination, and this list of grounds is supplemented with other legislations.

Paragraph 4 of the same article stipulates that "special measures which the Republic of Serbia may introduce to achieve full equality of individuals or group of individuals in a substantially unequal position compared to other citizens" are not deemed to be discrimination, meaning that these special measures represent a possibility, rather than constitutional obligation. The Constitution includes a couple of additional provisions relevant for the equality of national minorities. Thereby, Article 49 prohibits "inciting of racial, ethnic, religious or other inequality or hatred", while Article 76 particularly deals with the discrimination of national minorities and stipulates that introduction of "specific regulations and provisional measures which the Republic of Serbia may introduce in economic, social, cultural and political life for the purpose of achieving full equality among members of a national minority and citizens who belong to the majority" shall not be considered discrimination. The aforementioned constitutional provisions concerning measures of affirmative action are regulated in detail under Article 4 (3) of the Law on the Protection of Rights and Liberties of National Minorities ${ }^{43}$ and Article 14 of the Law on the Prohibition of Discrimination. ${ }^{44}$

The Law on the Prohibition of Discrimination, adopted in 2009 after a long and discordant hearing, guarantees that the citizens are equal and that they, as such, enjoy equal legal protection, regardless of their personal characteristics. ${ }^{45}$ The types of discrimination envisaged by this law include "direct and indirect discrimination, as well as breaching of the principle of equal rights and obligations, calling to account, association for the purpose of practising discrimination, hate speech and harassment and degrading treatment". ${ }^{4}$ In its Article 13, the Law stipulates seven forms of severe

42 Art. 21, Para 3, Constitution of the Republic of Serbia, Official Gazette of RS, No. 98/06.

43 Law on the Protection of Rights and Liberties of National Minorities, Official Journal of SRY, No. 11/02, Official Journal of SCG, No. 1/03 - Constitutional Charter and Official Gazette of RS, No. 72/09, 97/13 - decision of the Constitutional Court, 47/18.

44 Law on the Prohibition of Discrimination, Official Gazette of RS, No. 22/09.

45 Article 4 Paragraph 1 of the Law on the Prohibition of Discrimination, Official Gazette of RS, No. 22/09.

46 Article 5 of the Law on the Prohibition of Discrimination, Official Gazette of RS, No. $22 / 09$. 
discrimination, where for the context of the protection of Roma rights, particularly important are the following two: "causing and inciting inequality, hatred and enmity on the grounds of national, racial or religious affiliation, language, political opinions, gender, gender identity, sexual orientation or disability" and "discrimination that is committed a number of times (repeated discrimination) or is committed over an extended period of time (extended discrimination) against one and the same individual or a group of persons". The present law does not explicitly recognise segregation as a type of discrimination, while in practice this is the problem that Roma most frequently encounter. Therefore, the present Draft of the Law on Amendments to the Law on the Prohibition of Discrimination, for which the public hearing was finalised on 23 March 2021, envisages segregation as one of severe forms of discrimination. ${ }^{47}$ The Draft Law also includes obligation by employers to undertake "appropriate measures in order to facilitate access, participation, training and professional advancement of the employees in unequal position with respect to other employees, especially persons with disabilities, members of national minorities, women, etc."

In its articles 15-27, the Law on the Prohibition of Discrimination regulates cases of discrimination in particular social spheres, circumstances and properties, such as discrimination before public administration organs, in the sphere of labour, in the provision of public services, in the sphere of education and vocational training, while the discrimination of national minorities is separately regulated. However, in different reports, and also confirmed in the aforementioned research by the Institute of Social Sciences (Graph 1), it is indicated that Roma are affected by the majority of special cases of discrimination stipulated by the Law. In addition to these data which indicate permanent discrimination, one should take into account the data of the Commissioner for the Protection of Equality from her Regular Annual Report for 2020, where she determined that national affiliation and ethnic origin are the third most frequent basis for discrimination in the complaints filed by citizens, and that in the previous four years, the rise in the number of such complaints was perceived. There were 114 such complaints, making $15 \%$ of the total number of discrimination complaints. The largest number of these complaints, 94 (50 in 2019) of them, were filed for discrimination against members of the Roma national minority, which is as much as $82 \%$ (64\% in 2019) of the total number of the complaints concerning violations of the right to equality on the grounds of national or ethnic affiliation. ${ }^{48}$

47 Public Hearings, Ministry for Human and Minority Rights and Social Dialogue of the Republic of Serbia, (https://minljmpdd.gov.rs/javne-rasprave.php, 2. 4. 2021).

48 Regular Annual Report of the Commissioner for the Protection of Equality for 2020, 2021, Belgrade, p. 12, (http://ravnopravnost.gov.rs/wp-content/uploads/2021/04/Poverenik-za-zastitu-ravnopravnosti-Godisnji-izvestaj-za-2020.pdf, 9. 4. 2021). 
The Strategy on the Prevention of and Protection from Discrimination ${ }^{49}$ which was implemented between 2013 and 2018, identified specific goals concerning national minorities and sensitive social groups, where Roma were particularly addressed in item 4.2.2.3. Problems in which discrimination against Roma is particularly pronounced (unavailability of personal documents, segregation in education and housing, employment) were separately analysed, and it was recommended that, in line with then valid Strategy for the Advancement of the Position of Roma, particular attention should be paid to combating discrimination against the members of this national minority. The effects of this strategic document in relation to eliminating discrimination against Roma, were not examined accordingly, but on the basis of the Report by the Commissioner for the Protection of Equality for 2019 and report by the Belgrade Centre for $\mathrm{Hu}$ man Rights for 2020, it may be concluded that "members of the Roma national minority, in spite of the efforts to eradicate intolerance from the society and the legal framework for the protection of minority rights, are still exposed to discrimination, intolerance and hate speech". ${ }^{50}$

The Law on the Prohibition of Discrimination regulates judicial protection from discrimination in its Section 6. What is particularly important is the fact that this law has introduced into the legal and social life of the country Commissioner for the Protection of Equality, the position of which is defined in a general and seemingly incomplete way, as an "independent state organ, independent when it comes to performing the tasks prescribed by this Law" (Article 1). Section 4 regulates the election procedure, mandate, competences and other issues relevant for the work of the Commissioner.

According to the results quoted in the research by the Minority Rights Group, Roma respondents did not show trust in the Commissioner's work, mostly due to the lack of activity in local communities, slow and selective initiation of the proceedings concerning violations of the right to equality of the members of the Roma national minority and, finally, their perception that she failed to contribute to public condemnation of such discrimination and make the number of cases of discrimination decrease. Furthermore, other participants in the focus groups, lawyers representing Roma and representatives of the civil society organisations advocating for Roma rights, indicate that they lack direct communication with the Commissioner, and that courts neglect Commissioner's opinions when deliberating in the cases of discrimination. The problem that they emphasise is that the opinions and recommendations of this body

49 Strategy of the Prevention of and Protection against Discrimination, Official Gazette of RS, No. 60/13.

50 Ljudska prava u Srbiji 2020, 2021, Beograd, Beogradski centar za ljudska prava, p. 358; Shortened Regular Report by the Commissioner for the Protection of Equality for 2019, 2020, Belgrade, Commissioner for the Protection of Equality, p. 61. 
are not obliging and competent authorities thus often do not implement them and, finally, that greater number of strategic civil proceedings is missing from the work of the Commissioner, to serve as the basis for institutional combating against discrimination. In addition to that, it is also unfavourable for the efforts against discrimination that the Commissioner does not have authorities that would allow for the monitoring of implementation of the recommendations and opinions pronounced in the cases where discrimination was confirmed. ${ }^{51}$

It is important to highlight that the data of the Commissioner concerning the complaints and proceedings pertaining to violations of equality based on the national or ethnic affiliation, are not segregated and thus there are difficulties in analysing the complaints pertaining to discrimination of Roma, as well as corresponding proceedings.

\subsection{MEASURES OF AFFIRMATIVE ACTION}

The prohibition of discrimination in the Republic of Serbia is also contained in other legislation containing anti-discriminatory provisions. Moreover, in addition to the Constitution and anti-discriminatory legislation, measures of affirmative action are also contained in other regulations, especially those dealing with spheres such as education and employment. These measures should serve as the basis in creating the conditions for the social equality of Roma, yet they are not accepted by the professional public in a manner which would enable their effective implementation.

This is additionally enhanced by the prejudices against Roma, generally large number of poor citizens, extremely slight acquaintance of the public with the social and economic importance of eliminating discrimination and poverty, but also the fact that examples of good anti-discriminatory practices and affirmative action measures are not abundant. In the European Union, there is no unique strategy or policy of affirmative action measures towards vulnerable groups. With the aforementioned directives, recommendations and the establishment of anti-discriminatory instruments and bodies, the European Commission has outlined the basis upon which public policies will be developed, where affirmative measures will serve as a lever in securing normative and factual equality of the vulnerable groups' members. Such public policies vary from state to state, while the success in implementing affirmative measures depends on whether such measures are socially accepted, or clearly stipulated, and whether the conditions for their uniform implementation in local communities have been secured. ${ }^{52}$

51 Bašić, G., 2021, p. 14.

52 Bašić, G., 2014, Siromaštvo Roma i afirmativne mere, u: Várady, T. et al. (eds.), Prilozi Strategiji unapređenja položaja Roma, Beograd, Srpska akademija nauka i umetnosti i Zaštitnik građana, pp. 9-26. 
Serbia has adopted the measures of enrolling Roma students into secondary education ${ }^{53}$ and faculties, ${ }^{54}$ as well as the measures of active employment, yet their effectiveness when it comes to social inclusion, the essence of which is elimination of discrimination and its consequences, is not as it has been expected. ${ }^{55}$ What is more, according to the testimonies of the Roma respondents in the focus groups organised during the research project on the discrimination against Roma in Serbia, occurrence of discrimination is frequent in education, on the labour market and when it comes to realisation of one's right to labour and the related rights. ${ }^{56}$ Let us remember that the aforementioned research project by the Institute of Social Sciences indicated that as much as $56.9 \%$ of Roma have encountered discrimination more than ten times during their schooling, while $57.9 \%$ of them have experienced discrimination with the same frequency on the labour market. ${ }^{57}$

\subsection{FREE LEGAL AID AND ACCESS TO JUSTICE}

The confusion pertaining to the institute of free legal aid, legally regulated since $2018,{ }^{58}$ additionally hinders the effectiveness of combating discrimination against Roma. The Law on Free Legal Aid stipulates that three groups of citizens have the right to this type of support: the first involves those who qualify for welfare and child allowance; the second involves those who do not qualify for welfare and child allowance, yet they would be at risk of becoming the beneficiaries of these types of support should they be forced to pay for legal aid in these concrete cases; finally, the third group of potential beneficiaries includes members of socially "vulnerable" groups. ${ }^{59}$ The law defines thirteen such groups, including children, persons with disabilities, victims of domestic violence, torture and human

53 Rulebook on the Enrolment of Students in Secondary Schools, Official Gazette of RS, No. 76/20, 94/20.

54 Professional Instruction by the Minister of Education for realisation of the enrolment in the first year of basic and integrated study programmes in the higher education institutions founded by the Republic of Serbia for 2020/2021 school year. (http://www. eknfak.ni.ac.rs/dl/2020/Strucno\%20uputstvo\%202020.\%20godina.pdf, 5. 4. 2021)

55 See special reports by the Ombudsperson for 2013 and 2019, concerning the implementation of the strategy of integration and inclusion of Roma, as well as the EU Commission staff working document Serbia 2020 Report, Brussels, 6 October 2020, p. 40, (https://ec.europa.eu/neighbourhood-enlargement/sites/near/files/serbia_report_2020. pdf, 5. 4. 2021).

56 Bašić, G., 2021, pp. 6-12.

57 Bašić, G. et al., 2020, pp. 273-274.

58 Law on Free Legal Aid, Official Gazette of RS, No. 87/18.

59 Art. 4. 
trafficking, asylum seekers, refugees, legally invisible persons and persons involved in the procedures of eviction or forced relocation. In other words, Roma are not recognised as a particularly vulnerable group in this Law.

For the majority of members of the Roma national minority, the procedure of obtaining free legal aid is very complex. According to the Law, the person seeking free legal aid should turn to the LSGU officer who had necessary training for implementation of the Law on Free Legal Aid and received the accreditation of the Ministry of Justice. The LSGU officers are left the discretionary right to decide on the applications, which also includes rejection of such applications. In case the officer establishes that an applicant is entitled to free legal aid, he/she refers the applicant to the local self-government unit or to a lawyer, depending on the case. The manner of the allocation of the concrete service provider is regulated by a bylaw ${ }^{60}$ which has left unclear the issues of sequence and expediency of the referral of beneficiaries to free legal aid, and is simultaneously susceptible to various interpretations. Even though there are other uncertainties concerning the effectiveness of the right to free legal aid, we should particularly highlight the system of funding of this institute. Namely, while the free legal aid by the local self-government units is funded out of the local budget, the free legal aid provided by lawyers is charged in line with the lawyers' fee adopted by Serbian Government, while citizen's associations, which may provide this service only in line with the legal provisions which regulate the right to asylum and prohibition of discrimination, cover their fees from donations and projects. ${ }^{61}$ Thereby, the scope of the free legal aid by such associations is quite limited, meaning that members of the Roma national minority are prevented from receiving free legal aid by such associations in the cases concerning their human right not to endure discrimination. This solution is especially restrictive, bearing in mind the complexity of human rights and the fact that both experience and specialisation in dealing with human rights are more frequent among the lawyers working in citizen's associations, than those performing regular practice, or working in local self-government units.

In the research "Realisation of the Right to Free Legal Aid in the Autonomous Province of Vojvodina in 2017" Vojvodina Ombudsperson concludes, and this conclusion may be applied to the condition in other parts of the country, that: "a large number of the citizens of the Autonomous Province of Vojvodina has no possibility of obtaining legal aid, except when they turn to a lawyer who provides this service professionally and

60 Rulebook on the Referral of Applicants to the Providers of Free Legal Aid, Official Gazette of RS, No. 68/19.

61 See: Ljudska prava u Srbiji 2019, Beograd, Beogradski centar za ljudska prava, 2020, pp. 72-73. 
takes compensation for it. For these citizens, realisation of the right to legal aid and equal access to justice are conditioned by their material status. Bearing in mind the socio-economic position of our country's citizens, the question arises of the extent to which they can actually realise their right to equal access to justice." 62

Finally, access to justice and effective elimination of discrimination should be secured by local self-governments, which, under the Law on Local Self-Government, were entrusted with realisation, protection and improvement of human and minority rights, as well as protection of the rights of vulnerable groups. ${ }^{63}$ One of the ways in which local self-governments could contribute to combating discrimination is the establishment of independent monitoring bodies and through the proactive approach with the citizens most frequently exposed to discrimination. However, local ombudspersons, who could play a significant role in combating discrimination in local communities, were established in only 20 LSGUs and 3 Belgrade municipalities. These bodies, which should enable higher quality of local administration to citizens, and facilitate access to rights, were thus established in merely one in eight local self-government units. It is true that the local ombudspersons, just like the state and provincial ones, do not have direct competences pertaining to the protection of equality, as this is the authority of the Commissioner, but it is also true that local ombudspersons could contribute to a decrease in discrimination, especially those types of discrimination that citizens may encounter when realising their rights before local self-government authorities.

The Law on Local Self-Government in its Article 97 stipulates that "an Ombudsperson may be established in a unit of local self-government who will be authorised to control citizens' rights being respected, determine violations of local self-government units' regulations and general acts by actions or omissions", while the establishment of authorities, competences and procedures is left in this Law to the local self-government units, to be realised through a statute or another general act. Even though that in their daily work, local ombudspersons, in cases of violations of the right to equality, usually refer the citizens to judiciary, or the Commissioner, we can also find some examples of proactive efforts by the local ombudspersons in combating discrimination. Namely, The Ombudsperson for the City of Novi Sad, in line with the City Statute ${ }^{64}$ and articles $21 \& 22$ of

62 Ostvarivanje prava na besplatnu pravnu pomoć u AP Vojvodina u 2017. godini, 2018, Novi Sad, Pokrajinski zaštitnik građana, p. 14.

63 Art. 20, Para 1, Items 5 and 10, Law on Local Self-Government, Official Gazette of RS, No. 129/07, 83/14, 101/16 and 47/18.

64 Statute of the City of Novi Sad, Official Gazette of the City of Novi Sad, No. 11/19. 
the Decision on the Local Ombudsperson ${ }^{65}$ has the authority to act within the established competences in a manner which raises awareness and the level of knowledge of the city administration employees, pertaining to the realisation of human rights and combating discrimination.

All in all, in spite of the developed anti-discriminatory system and the national strategies of the social inclusion of Roma and of combating discrimination, its consequences have not been eliminated, making the camouflaged impact of the discrimination just as severe as before the adoption of said measures. One of the reasons for such situation is the aforementioned weakness of the judicial system, in which opinions and recommendations by the Commissioner are not paid due attention. ${ }^{66}$ In relation to this are the findings that the court proceedings concerning the discrimination of Roma are inexcusably long. The opinion of the lawyers and CSOs representing citizens in the cases of violated human rights is that the access to the judicial system is not efficient, despite the fact that the Law on Protection of the Right to Trial within Reasonable Time, ${ }^{67}$ which regulates legal instruments to protect this right, including the right to financial compensation and compensation for material damage, has been in effect since 1 January 2016. According to the report by the Belgrade Centre for Human Rights on the operation of courts in the first six months of 2019, at the end of June, there were 732,991 cases in Serbia where the proceedings had lasted for more than two years, counting from the submission of the initiating act. The number of such cases without execution was 144,878 . During these six months, the total of 148,271 old cases were solved, while 93,537 cases were without execution. In the higher courts in Serbia, on the day of 30 June 2019, there were 1,337 cases older than 10 years concerning all matters, while primary courts had 254,564 such cases. ${ }^{68}$

\section{Conclusion}

Roma face discrimination based on the nationality (ethnicity) daily. It is contained in the actions of their fellow citizens, but also of the authorities and organisations before which they realise their rights. The system of the prohibition of and protection from discrimination is established, more or less in line with the standards applied in the European

65 Decision on the Local Ombudsperson, Official Gazette of the City of Novi Sad, No. $59 / 19$.

66 Bašić, G., 2021, p. 18.

67 Law on Protection of Right to Trial within Reasonable Time, Official Gazette of RS No. 40/15.

68 Ljudska prava u Srbiji 2019, p. 358. 
Union, yet some shortcomings have been identified, including the fact that the Commissioner for the Protection of Equality does not have the authority to initiate proceedings on his/her own initiative, or the shortcomings pertaining to the access to justice, while the absence of a consistent strategy for combating discrimination does not contribute to the discrimination against Roma to become visibly less blatant. A separate problem is that, providing the social dimension of the problem, the Commissioner did not initiate more strategic civil proceedings or adopted more opinions and recommendations to help with the design of the national standards and practice of combating discrimination. The exception is the Opinion ${ }^{69}$ in which it is established that segregation of students in the education system is a form of discrimination based on their nationality, where the Commissioner has indubitably highlighted personal and social damage made by segregating students of the Roma nationality into separate classes or schools. Finally, the absence of awareness among judges that they need to take into account opinions of the Commissioner when deliberating in the proceedings concerning discriminatory or similar action (hate speech), points to the hypocrisy of the national strategies for combating discrimination.

Adoption of a new Strategy for Combating Discrimination is inevitable in the following period and it should include, based on the determined facts and desegregated data, measures that are as concrete as possible in eliminating discrimination against Roma and alleviating its consequences, as well as measures to raise public awareness of the concept of discrimination and the harmfulness of discriminatory actions and behaviours, and of the protection mechanisms. Furthermore, amendments to the Law on the Prohibition of Discrimination need to be made, in order to strengthen the legal and social role of the Commissioner for the Protection of Equality, as well as to define segregation as a severe form of discrimination. Strengthening of the trust in the institution of the Commissioner would be contributed by promoted transparency of his/her work, well-conceived strategic civil proceedings and finally, the manner of the Commissioner election, starting with the public call and finalised by the election in the National Assembly. Amendments to the Law also need to widen the scope of the Commissioner's competences when it comes to pronouncing measures in the cases of confirmed discrimination, initiation of proceedings without prior reception of complaints, establishment of the obligation when it comes to applying opinions by the Commissioner and monitoring of the application of those opinions by the Commissioner.

69 Opinion of the Commissioner for the Protection of Equality, no. 07-00-1328/2018-02 of 28 March 2019. 
Combating the discrimination of Roma would also be contributed to by creatively designed anti-discriminatory programmes in the public policies of education, culture and information (media), in which the society would be clearly influenced to condemn discrimination and hate speech, and promote interculturality. Finally, redefinition of the institute of free legal aid by expanding the scope of competent providers of the service and the definite allocation of funds to cover the costs of proceedings to the persons who have experienced proven discrimination, would clearly encourage citizens to file complaints and initiate corresponding proceedings.

Combating the discrimination of Roma should be conceived holistically in the system of public administration, so it would be advisable to also revise the Strategy for the Social Inclusion of Roma Men and Women, which lacks the modern EU approach ${ }^{70}$ in combating discrimination and antigypsyism. Public policies of the social inclusion of Roma men and women, which also imply elimination of discrimination, must be based on facts, strengthening of the capacities of public authorities for implementation of the Strategy and combating against discrimination, and effective involvement of Roma in the public administration affairs concerning these processes.

It needs to be repeated that institutional changes and strengthening of the capacities of public administration, judiciary and independent bodies make sense only when accompanied and supported by social changes in the perception of discrimination through appropriate education, integrative cultural policy and responsible media.

The last but not the least, institutional measures of Roma integration and inclusion have direct impact on the Roma identity and its changes. The measures implemented in the past with the purpose of improving the position of Roma mostly led to assimilation of the Roma population, or caused changes in the traditional behavioural patterns, language and customs comprising the national identity of the Roma people. The policies of Roma inclusion which do not take into account the specific characteristics of Roma as people, with some specific traits when it comes to their culture (Rromanipen), language (Rromani ćhib) or tradition (Rromani kris), may lead to consequences that are just as detrimental, if not even more so, than those caused by discrimination.

70 See: EU Roma strategic framework for equality, inclusion and participation for 2020 2030, Brussels, Communication from the Commission to the European Parliament and the Council, A Union of Equality: EU Roma strategic framework for equality, inclusion and participation, Brussels, 7 October 2020, (https://ec.europa.eu/info/ sites/info/files/eu_roma_strategic_framework_for_equality_inclusion_and_participation_for_2020_-_2030_0.pdf, 3.4.2021). 


\section{BIBLIOGRAPHY}

1. Acković, D., 2009, Romi u Beogradu: istorija, kultura i tradicija Roma u Beogradu od naseljavanja do kraja XX veka, Beograd, Rominterpres.

2. Bašić, G. et al., 2020, Istraživanje socijalnih odnosa između etničkih zajednica u Srbiji, Beograd, Centar za istraživanje etniciteta i Institut društvenih nauka. (http:// idn.org.rs/sr_lat/wp-content/uploads/2020/09/SOCIJALNA-DISTANCA-ETNICKIH-ZAJEDNICA-IZVESTAJ.pdf, 15. 3. 2021).

3. Bašić, G., 2010, Političa akcija - romski pokret i promene, Beograd, Čigoja.

4. Bašić, G., 2014, Siromaštvo Roma i afirmativne mere, u: Várady, T. et al. (eds.), Prilozi Strategiji unapređenja položaja Roma, Beograd, Srpska akademija nauka i umetnosti \& Zaštitnik građana.

5. Bašić, G., 2021, Roma in the Republic of Serbia: The Challenges of Discrimination, Minority Rights Group, London.

6. Beogradski centar za ljudska prava, 2020, Ljudska prava u Srbiji 2019, Beograd.

7. Beogradski centar za ljudska prava, 2021, Ljudska prava u Srbiji 2020, Beograd.

8. Chopin, I., Germaine, C., Tanczos, J., 2017, Roma and the Enforcement of Anti-Discrimination Law, European Commission, Directorate-General for Justice and Consumers.

9. Civil Rights Defenders, 2018, The Wall of Anti-Gypsyism - Roma in Serbia, (https://crd.org/wp-content/uploads/2018/03/The-Wall-of-Anti-Gypsyism-Roma-in-Serbia.pdf, 7. 4. 2021).

10. Commissioner for the Protection of Equality, 2020, Shortened Regular Report by the Commissioner for the Protection of Equality for 2019, Belgrade.

11. Commissioner for the Protection of Equality, 2021, Regular Annual Report of the Commissioner for the Protection of Equality for 2020, Belgrade, (http:// ravnopravnost.gov.rs/wp-content/uploads/2021/04/Poverenik-za-zastitu-ravnopravnosti-Godisnji-izvestaj-za-2020.pdf, 9. 4. 2021).

12. Courthiade, M., 2018, Consolidating the Standardization of the Romani Language - Past, Present, Future, in Respect of Dialectal Diversity while Granting Easy Worldwide Communication in Mother Tongue, in: Sikimić, B., Varady, T., Očuvanje, zaštita i perspektive romskog jezika u Srbiji, SASA, Beograd.

13. EU Agency for Fundamental Rights Coronavirus pandemic in the EU - impact on Roma and Travellers - Bulletin 5, 2020, (https://fra.europa.eu/en/publication/2020/covid19-rights-impact-september-1, 27. 3. 2021).

14. Fejzula, S., 2019, The Anti-Roma Europe: Modern Ways of Disciplining the Roma Body in Urban Spaces, Revista Diretio e Praxis, Vol. 10, No. 3, Rio de Janeiro July/ Sept.

15. Hancock, I., 1995, Posledice anti-romskog rasizma u Evropi, Pravo i rat, Beogradski krug.

16. Ignãțoiu-Sora, E., 2011, The Discriminations Discourse in Relation to the Roma: Its Limist and Benefits, Ethnic and Racial Studies, Vol. 34, Issue 10.

17. Jakšić, B., 2015, Romi u Srbiji između nakovnja siromaštva i čekića diskriminacije, Beograd, MostArt. 
18. Korunkovska, N., Jovanović, Ž., 2020, Roma in the COVID-19 Crisis - An Early Warning from Six EU Member States, Open Society Foundatition.

19. Macura, Z., 2015, Život na ivici stanovanje beogradskih Roma, Beograd, Galerija SANU.

20. Matasović, J., 1928, Cigani u doba terezijanstva i jozetinizme, Zagreb, Narodna starina.

21. Mirga, A., 1987, The Category of "Romanipen" and the Ethnic Boundaries of Gypsies, Ethnologia Polona, No. 13.

22. Nicolae, V., Towards a Definition of Anti-Gypsyism, in: Nicolae, V., Slavic, H., (eds.), 2007, Roma Diplomacy, International Debate Education Association, New York, DiploFoundation.

23. Pisari, M., 2014, Stradanje Roma u Srbiji za vreme Holokausta, Beograd, Forum za primenjenu istoriju.

24. Pokrajinski zaštitnik građana 2018, Ostvarivanje prava na besplatnu pravnu pomoć u AP Vojvodina u 2017. godini, Novi Sad.

25. Ram, M., 2007, Anti-discrimination Policy and the Roma Assessing the Impact of EU Enlargement, Croatian Yearbook of European Law \& Policy, No. 3.

26. Soulis, G. C., 1961, The Gypsies in the Byzantine Empire and the Balkans in the Late Middle Ages, Dumbarton Oaks Paper, Vol. 15, Harvard University.

27. Stojančević, V., Politički i pravni položaj Cigana (Roma) u Srbiji Prvog i Drugog ustanka, in: Macura, M., (ed.), 1992, Razvitak Roma u Jugoslaviji, problemi i tendencije, Beograd, Srpska akademija nauka i umetnosti.

28. Tejlor, Č., 2000, Politika priznanja, Habitus, No. 1, Novi Sad.

29. Trubeta, S., 2003, Gypsiness, Racial Discourse and Persecution: Balkan Roma during the Second World War, Nationalities Papers The Journal of Nationalism and Ethnicity, Vol. 31.

30. Weyrauch, W., 2001, Gypsy Law Romani Legal Traditions and Culture, University of California Press.

\section{Legal ACts}

1. Constitution of the Republic of Serbia, Official Gazette of RS, No. 98/06.

2. Decision on the Local Ombudsperson, Official Gazette of the City of Novi Sad, No. 59/19.

3. EU Council Directive 2000/43/EC of 29 June 2000 implementing the principle of equal treatment between persons irrespective of racial or ethnic origin (OJL 180, 19. 7. 2000).

4. EU Council Directive 2000/78/EC of 27 November 2000 establishing a general framework for equal treatment in employment and occupation (OJL 303, 2. 12. 2000).

5. Law on Free Legal Aid, Official Gazette of RS, No. 87/18.

6. Law on Local Self-Government, Official Gazette of RS, No. 129/07, 83/14, 101/16, 47/18.

7. Law on Protection of Right to Trial within Reasonable Time, Official Gazette of RS, No. 40/15. 
8. Law on the Prohibition of Discrimination, Official Gazette of RS, No. 22/09.

9. Law on the Protection of Rights and Liberties of National Minorities, Official Journal of SRY, No. 11/02, Official Journal of SCG, No. 1/2003 - Constitutional Charter and Official Gazette of RS, No. 72/09, 97/13 - decision of the Constitutional Court, $47 / 18$.

10. Professional Instruction by the Minister of Education for realisation of the enrolment in the first year of basic and integrated study programmes in the higher education institutions founded by the Republic of Serbia for 2020/2021 school year.

11. Rulebook on the Enrolment of Students in Secondary Schools, Official Gazette of $R S$, No. 76/2020 \& 94/2020.

12. Rulebook on the Referral of Applicants to the Providers of Free Legal Aid, Official Gazette of RS, No. 68/19.

13. Statute of the City of Novi Sad, Official Gazette of the City of Novi Sad, No. 11/19.

14. Strategy for the Prevention of and Protection from Discrimination, Official Gazette of RS, No. 60/13.

15. Strategy for the Social Inclusion of Roma Men and Women in the Republic of Serbia for the period of 2016-2025, Official Gazette of RS, No. 26/16.

\section{INTERNET SOURCES}

1. Council recommendation on effective Roma integration measures in the member States - employment, social policy, health and consumer affairs, Council meeting, Brussels, December 9-10, 2013, (https:/www.consilium.europa.eu/uedocs/ cms_data/docs/pressdata/en/lsa/139979.pdf, 15. 4. 2021).

2. EU Commission staff working document Serbia 2020 Report, Brussels, 6 October 2020, p. 40, (https://ec.europa.eu/neighbourhood-enlargement/sites/near/files/ serbia_report_2020.pdf, 5. 4. 2021).

3. Factsheets - Roma and Travellers, (https://www.echr.coe.int/documents/fs_roma_ eng.pdf, 2. 3. 2021).

4. Institucionalizacija i emancipacija, 2010, Romi i istorija. No. 6.2, Savet Evrope, (https://rm.coe.int/institucionalizacija-i-emancipacija-informativna-brosura-o-istoriji-ro/16808b1c67, 31. 3. 2021).

5. Public Hearings, Ministry for Human and Minority Rights and Social Dialogue of the Republic of Serbia, (https://minljmpdd.gov.rs/javne-rasprave.php, 2. 4. 2021).

\section{OTHer Sources}

1. COM/2018/785: Communication From the Commission to the European Parliament and the Council, Report on the evaluation of the EU Framework for National Roma Integration Strategies up to 2020.

2. ECRI General Policy Recommendation No. 13 revised on combating antigypsyism and discrimination against Roma - adopted on 24 June 2011 and amended on 1 December 2020. 
3. EU Roma strategic framework for equality, inclusion and participation for 20202030, Brussels, Communication from the Commission to the European Parliament and the Council, A Union of Equality: EU Roma strategic framework for equality, inclusion and participation, Brussels, 7 October 2020, (https://ec.europa. $\mathrm{eu} / \mathrm{info} / \mathrm{sites} / \mathrm{info} / \mathrm{files} / \mathrm{eu}$ _roma_strategic_framework_for_equality_inclusion_ and_participation_for_2020_-_2030_0.pdf, 3.4.2021).

4. Interview, Poverenica: Romi su izloženi diskriminaciji u svim oblastima života, Beta, 2020, (https://rs.n1info.com/vesti/a683369-poverenica-romi-su-izlozenidiskriminaciji-u-svim-oblastima-zivota/, 9. 4. 2021).

5. Interview, Željko Jovanović: Ne možemo više da čekamo da EU, međunarodne organizacije i donatori vode našu politiku, 2019, the Udar internet portal, (http:// www.portal-udar.net/zeljko-jovanovic-ne-mozemo-vise-da-cekamo-da-eu-medunarodne-organizacije-donatori-vode-nasu-politiku/, 5. 4. 2021).

6. Opinion of the Commissioner for the Protection of Equality, no. 07-00-1328/2018-02 of 28 March 2019.

\title{
DISKRIMINACIJA I IDENTITET ROMA U SRBIJI
}

\author{
Goran Bašić \\ Ivana Stjelja
}

APSTRAKT

Rad je napisan na osnovu savremene pravne, sociološke i antropološke literature o problemima diskriminacije i integracije Roma i na osnovu podataka iz dva istraživanja koja smo sproveli u 2020. godini: „Istraživanje socijalnih odnosa etničkih zajednica u Srbiji“ (Institut društvenih nauka) i "Roma Equality through Increased Legal Access" (Minority Rights Group). Rezultati prvog istraživanja su zasnovani na podacima prikupljenim kvantitativnim metodama (nacionalni internet uzorak i terensko istraživanje), a podaci iz drugog istraživanja su prikupljeni kvalitativnim metodama, odnosno u razgovorima sa 42 sagovornice i 17 sagovornika na osam fokus grupa. Dovođenjem u vezu empirijskih podataka o diskriminaciji građana romske nacionalnosti sa pravnim sistemom koji bi trebalo da suzbija i postepeno eliminiše svaki oblik diskriminacije ukazuje se na dubinu socijalne dimenzije ovog fenomena, ali i na nedorečenosti i slabosti samog sistema.

Ključne reči: Romi, diskriminacija, antiromizam, socijalna inkluzija.

Article History:

Received: 24 April 2021

Accepted: 1 June 2021 